\title{
An X-Ray of the Brazilian e-Gov Web Sites
}

\author{
Cristiano Maciel, José Luiz T. Nogueira, and Ana Cristina Bicharra Garcia \\ Universidade Federal Fluminense, \\ Rua Passos da Pátria, 156 sl 326, Niterói, RJ, Brazil \\ \{cmaciel, nogueira, bicharra\}@ic.uff.br
}

\begin{abstract}
The digital inclusion promotes the reduction of social inequalities. Based on this principle, the Brazilian Government has been setting up an increasing number of Web access locations to render virtual support to its citizens. However, there are no guidelines for the construction and assessment of these electronic Government (e-Gov) sites. In this article we measure the web site quality in the e-Gov domain with the following proprieties: usability, accessibility, interoperability, security, privacy, information reliability, and service agility. We implemented our method, by using a checklist tool, in the evaluation of 127 Brazilian government sites (federal, state and municipal). Our method proved itself efficient in the diagnosis and identification of specific problems in the e-Gov site domain.
\end{abstract}

\section{Introduction}

Electronic government (e-gov) means the use of information and communication technology: 1) to meet the citizens' needs regarding government information acquisition; 2) to render services (it allows on-line transactions of government products and services); 3) and to participate in government decisions (it permits citizen's participation through interaction with the government).

Brazil ranks eighteenth [1] in the group of countries that have top qualification in "e-government", presenting a higher rating than Italy, Japan and Austria. Nevertheless, several Brazilian studies indicate that these e-Gov sites do not meet Brazilian citizen needs [2]. Although these studies indicate that the sites are not good, they do not determine which are the specific problems, when applied to the information, services and citizen's participation categories.

This research is based on the indirect usability evaluation method, known as Heuristic Evaluation, and in Brazilian documents on eletronic government [5][6]. The heuristics, as defined by Nielsen [3][4], that were used to measure the usability property were: visibility of system status, match between system and the real world, user control and freedom, consistency and standards, error prevention, recognition rather than recall, flexibility and efficiency of use, aesthetics and minimalist design, help users recognize, diagnose, and recover from errors, and help and documentation. For the electronic government domain, the Nielsen's heuristics evaluation were not sufficient for site evaluations and, thus, require extensions to measure the quality of the e-Gov Web sites[07][08][09][10]. See in the Table 1 all properties investigated. 
Table 1. Proprieties to e-Gov Web site assessment

\begin{tabular}{l|l|l}
\hline \multicolumn{1}{c|}{ Proprieties } & \multicolumn{1}{|c|}{ Description } & \multicolumn{1}{c}{ Justification } \\
\hline Usability (Us) & $\begin{array}{l}\text { Traditionally associated with these } \\
\text { attributes: Learnability, Efficiency, } \\
\text { Memorability, Errors e Satisfaction [4]. }\end{array}$ & $\begin{array}{l}\text { This principle is ideal to interface } \\
\text { evalution. }\end{array}$ \\
\hline Accessibility (Ac) & $\begin{array}{l}\text { The site must be devised so as to ensure its } \\
\text { content is accessible to those with special } \\
\text { needs and from different environments. }\end{array}$ & $\begin{array}{l}\text { Digital inclusion of citizens with } \\
\text { special need makes electronic } \\
\text { government accessible to all. }\end{array}$ \\
\hline $\begin{array}{l}\text { Interoperability } \\
\text { (In) }\end{array}$ & $\begin{array}{l}\text { Ability to interchange information between } \\
\text { different systems, allowing data exchange } \\
\text { based on the government standard [6]. }\end{array}$ & $\begin{array}{l}\text { Allows a broader scope and } \\
\text { minimizing physical strain of } \\
\text { citizens who used other systems. }\end{array}$ \\
\hline $\begin{array}{l}\text { Security and } \\
\text { Privacy (SP) }\end{array}$ & $\begin{array}{l}\text { Personal information requiring privacy } \\
\text { should travel on the net security, without } \\
\text { risk for the users. }\end{array}$ & $\begin{array}{l}\text { Visibility of site security allows } \\
\text { users to interact with confidence. }\end{array}$ \\
\hline $\begin{array}{l}\text { Information } \\
\text { Reliability (IR) }\end{array}$ & $\begin{array}{l}\text { Inform last update on each page of the site. } \\
\text { Service Agility }\end{array}$ & $\begin{array}{l}\text { Up-to-date pages convey content } \\
\text { credibility and promote required } \\
\text { trust for interaction. }\end{array}$ \\
\hline $\begin{array}{l}\text { The site's response time should be brief or } \\
\text { (SA) instantaneous and denotes } \\
\text { transparency in governmental processes. }\end{array}$ & $\begin{array}{l}\text { Citizens expect prompt response } \\
\text { and any delay diminishes trust on } \\
\text { the site and increases intolerance. }\end{array}$ \\
\hline
\end{tabular}

To implement the method, the proprieties were charted on an evaluation table, with several items, in a manual checklist, used by specialists evaluators. This also quantified the migration scope, to the Web environment, in the three categories information, services, and participation.

The evaluation method was applied to 127 government domain sites [11]. The results demonstrated the method's efficiency, not only to diagnose but, also, to identify specific problems in e-Gov sites.

\section{Case Study}

In this section, to test the efficiency of the e-gov Web sites quality assessment a case study was presented. The proposed method was implemented to analyze the quality of Brazilian e-Gov sites, with the following breakdown: 9 federal sites, 91 municipal sites (all of them in Rio de Janeiro state) and 27 municipal sites (from Brazilian state capitals). All Web sites were evaluated in the totality of their pages. The quantitative data was presented in tables and graphs, so as to facilitate their qualitative analyses.

Figure 1 showed the behavior of the proprieties used in the evaluation. The checklist was composed of several sub-items for each property. Some of these were argued in this session.

Considering only "Usability" (Us) property, through the evaluation of the ten Nielsen's heuristics, there was $44,93 \%$ average, with the exception of the "usage flexibility and efficiency" $(1.95 \%)$ and "help and documentation" $(13,91 \%)$ heuristics. The best was the "consistency and standards" heuristic, with $68,55 \%$ of the sites.

The "Accessibility" (As) property was fundamental for this domain. No need of concern was found not even within federal sites. The checklist sub-item with "allows visual perception through text markers" was not taken into account by $83.70 \%$ of the 
sites. Meanwhile, the sub-item "Uses easy access resources through various means, cellular and palmtop" is not considered by $98.91 \%$, while $94.81 \%$ of the sites do not even "comply with W3C recommendations".

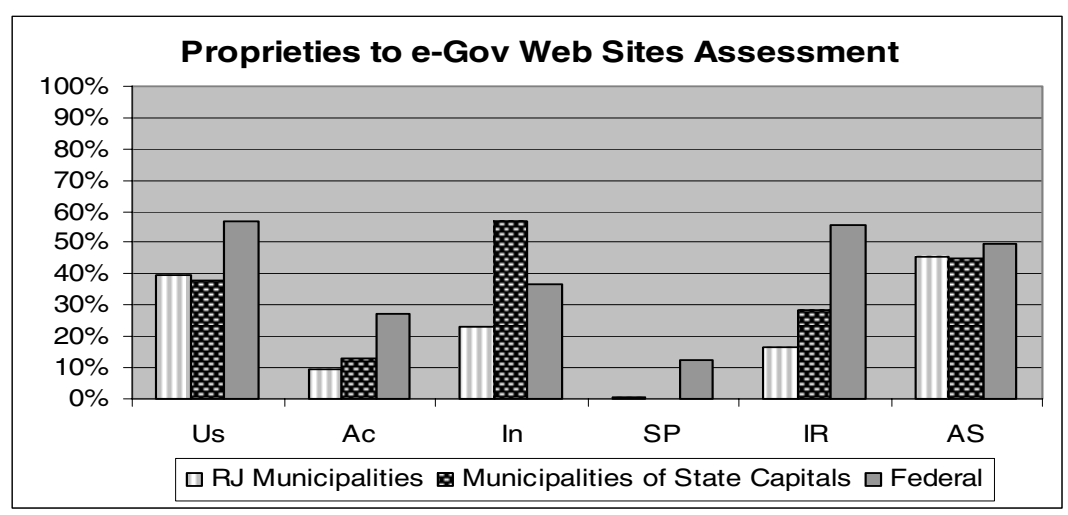

Fig. 1. Assessment of e-Gov Web Sites Proprieties

The "Interoperability" (In) property, in the analyzed federal sites, it was observed intense usage of proprietary formats. For the checklist sub-item "makes document available under patterns xml, swx, rtf, pdf, txt, htm or html", less than de $56 \%$ of the federal sites comply with this norm, while, in the overall evaluation, $69.74 \%$ of the evaluated sites were in compliance.

In the "Security and Privacy" (SP) property, evaluation results were much closer to 0 (zero), this being a noteworthy problem for this kind of domain. Upon analyzing the checklist sub-items, was found that $96.10 \%$ of the sites did not use "digital certification", while $100 \%$ did not "use virtual keyboard".

Looking into the "Information Reliability" (IR) property, 9 municipal sites were highly rated. In spite of this, as it could be observed, several municipalities show no concern with this issue, and this may generate a credibility failure towards the site, on the citizen's part. Upon analyzing the checklist sub-items, if was seen that $76.82 \%$ of the sites do not meet the sub-item "when necessary, informs last update of each page".

When it comes to the "Service Agility" (SA) property, less than 50\% of the sites meet this requirement satisfactorily. Upon analyzing the sub-items individually, it was verified that $21.74 \%$ of the sites do not "make available e-mail contact". Another hurdle is that $81.25 \%$ of the analyzed sites did not reply e-mails within the following 48 hours and, a month later, the situation was practically the same. The checklist subitems "renders public accout to citizens" and "it demonstrates the budgetary execution" had indicated low transparency in governmental processes.

\section{Discussions}

This study presents a Web sites quality assessment of government sites. The exclusive use of Nielsen Heuristics does not guarantee usability of electronic government sites, hence the incorporation of specific proprieties for the evaluation of this domain. 
Regarding the evaluated sites, it can be perceived that, in general, those of the federal sphere present better percentages in proprieties to e-gov Web sites assessment.

It was observed the existence of sites that purport to be official but are, in fact, business-oriented, portraying a totally distorted image of electronic government. Such proprieties - acessibility, information reliability and service agility - are absolutely necessary for the implementation of a viable electronic government system which users trust and feel at ease with. Another issue that should be highlighted is the lack of security of government sites. Provision of government services depends on strict security. Therefore, this proprieties is extremely important since citizens interacting with these systems need to feel totally secure.

During visits to sites evaluated in this research, it could be verified the existence of many important governamental information, but the citizen participation is limited, in most instances, to expressing opinion via e-mail (though it was verified that this option is not always available), and voting in restricted polls.

When issues are raised, which are relevant to both the citizen, and the government, a set of measures must be stablished $t$ evaluate e-Gov sites, so as to provide better quality. It is hoped that this research contributes to the process by raising new indicators to improve electronic government systems.

\section{References}

1. Benchmarking E-government: A Global Perspective. Assessed in July 2004. Available on http://www.unpan.org/.

2. Chalin, A. et all. E-gov.br: a próxima revolução brasileira: eficiência, qualidade e democracia. São Paulo: Prentice Hall. (2004). 380p. /in portuguese/

3. Nielsen, J. Usability Engineering. Boston: Academic Press, Cambridge, MA. (1993).

4. Nielsen, J. Usability Metrics. Assessed in May 2004. Available on http://www.useit.com/ alertbox/ 20010121.html.

5. e-Ping - Versão 1.0 do documento e-Ping. Assessed in October 2004. Available on http://www.governoeletronico.e.gov.br/governoeletronico/index.html. /in portuguese/

6. Governo Federal. Assessed in July 2004.Cartilha de Usabilidade para Sítios e Portais do Governo Federal - Versão 01 - 30/06/2004. /in portuguese/

7. Holliday, I; Kwok, R.C. Governance in the information age: building e-government in Hong Kong. New Media\&Society, 6(4), (2004) 549-570.

8. Mahammed, S.N. Self-presentation of small developing countries on the World Wide Web: A study of official Web sites. New Media \& Society, 6(4), (2004), 469-486.

9. Zazenlenchuk, T,. In Search of the Holy Grail: Alternatives to Nielsen's Heuristics. Assessed in Setember 2004. Available on http://www.indiana.edu/ usable/utips/ february_03.htm.

10. Zeithaml, V. A., Parasuraman, A. and Malhotra, A.. Service Quality Delivery through Web Sites: A Critical View of Extant Knowledge. Journal of the Academy of Marketing Science, Vol. 30, No. 4 (2002) 362-375.

11. Garcia, A.C.B.; Maciel, C.; Pinto, F. B. A Quality Inspection Method to evaluate eGovernment Sites. Lecture Notes in Computer Science, 2005. 